\title{
Admiralty Jurisdiction Over Asbestos Torts: Unknotting the Tangled Fibers
}

The Constitution places within the judicial power of the United States "all Cases of admiralty and maritime Jurisdiction," and Congress has vested original jurisdiction over such cases in the district courts. ${ }^{2}$ Once a federal court has found a case to be within its maritime jurisdiction, it normally will apply all "the substantive rules and precepts peculiar to the law of the sea." 3 In White $v$. Johns-Manville Corp.," the Fourth Circuit allowed a shipyard worker suffering from asbestosis to bring his products liability claim against the supplier of asbestos into federal court under the admiralty and maritime jurisdiction. The court thereby allowed the plaintiff in the case to avoid the bar that the Virginia statute of limitations would have placed on the action. ${ }^{5}$

The three-year statute of limitations on tort actions in admiralty $^{6}$ is one of several reasons litigants may find it advantageous to invoke admiralty jurisdiction. Three years may be longer than alternative state personal injury statutes of limitations and may therefore make the admiralty action more attractive to plaintiffs, even though (like admiralty) most states now hold that a cause of action for a long-latency injury accrues when the disease becomes manifest rather than at the time of exposure. ${ }^{7}$ In addition, plain-

1 U.S. Const. art. III, § 2, cl. 1.

2 Section 9 of the Judiciary Act of 1789 , codified as amended at 28 U.S.C. $\S 1333$ (1982), states that "[ $t]$ he district courts of the United States shall have original jurisdiction, exclusive of the courts of the States, of: (1) Any civil case of admiralty or maritime jurisdiction, saving to suitors in all cases all other remedies to which they are otherwise entitled."

${ }^{3}$ Branch v. Schumann, 445 F.2d 175, 178 (5th Cir. 1971).

- 662 F.2d 234 (4th Cir. 1981).

- Id. at 240.

- 46 U.S.C. § 763(a) (1982) states that "a suit for recovery of damages for personal injury or death, or both, arising out of a maritime tort, shall not be maintained unless commenced within three years from the date the cause of action accrued."

The equitable doctrine of laches applies to actions attempting to recover damages for a maritime tort accruing before 1980. See, e.g., Fordham v. Belcher Towing Co., 710 F.2d 709 (11th Cir. 1983).

7 Asbestosis and other asbestos-related diseases may not manifest themselves until up to twenty-five years from the date of the last exposure. See, e.g., Reserve Mining Co. v. EPA, 514 F.2d 492, 508 (1975) (twenty-year figure). Courts exercising their admiralty juris- 
tiffs may seek admiralty jurisdiction in order to avoid jury trials. ${ }^{8}$ But perhaps most importantly, asbestos manufacturers may wish to defend an asbestos case in admiralty in order to be able to recover from the United States as a third-party defendant. ${ }^{9}$

diction probably will hold that the statute of limitations starts to run from the date of the discovery of a long-latency occupational disease such as those caused by exposure to asbestos. For example, in Castorina v. Lykes Bros. S.S. Co., Inc., 758 F.2d 1025, 1029-31 (5th Cir. 1985), the court held that in long-latency industrial diseases, the cause of action accrues at the date of manifestation for the purpose of determining whether to apply the pre- or post1972 version of the Longshore and Harbor Workers' Compensation Act, codified as amended at 33 U.S.C. $\$ \$ 901-950$ (1982) ("LHWCA"). The court also indicated its approval of cases holding that the statute of limitations in cases of long-latency diseases does not start to run until the disease has become manifest. Id.

- See Owens-Illinois, Inc. v. United States Dist. Ct., 698 F.2d 967 (9th Cir. 1983).

- Under the LHWCA, the liability of an employer is exclusive: once an employer has paid the required compensation to an injured worker, the employer will not be liable to anyone else, including a third party sued by the employee, for damages arising out of the injury that led to the LHWCA claim. 33 U.S.C. $\$ 905$ (a).

In general, persons repairing asbestos insulation on ships are covered by the LHWCA. Section 902 of the LHWCA states:

(3) The term "employee" means any person engaged in maritime employment, including . . . any harbor worker including a ship repairman. . . .

(4) The term "employer" means an employer any of whose employees are employed in maritime employment, in whole or in part, upon the navigable waters of the United States (including any adjoining pier, wharf, dry dock, terminal, building way, marine railway, or other adjoining area customarily used by an employer in loading, unloading, repairing or building a vessel).

As the LHWCA was adopted as an exercise of, Gudmundson v. Cardillo, 126 F.2d 521, 525 (D.C. Cir. 1942), and coextensive with, Perry v. Baltimore Contractors, Inc., 202 So.2d 694, 700-01 (La. App. 1967), the federal maritime and admiralty jurisdiction, it might appear that the definitions of employer and employee would at once solve the problem of admiralty jurisdiction over workers involved in the repair or installation of asbestos insulation on ships. However, as the Supreme Court noted in Director, OWCP v. Perini North River Assocs., 459 U.S. 297 (1983), "[a]lthough the term 'maritime' occurs both in 28 U.S.C. $\S 1333(1)$ and in $\S 2(3)$ of the [Longshore and Harbor Workers' Compensation] Act, these are two different statutes 'each with different legislative histories and jurisprudential interpretations over the decades.' " 459 U.S. at 320 n.29 (citation omitted). Therefore, the asbestos claims of these workers are not brought within the admiralty jurisdiction simply because of the LHWCA.

Moreover, with one exception, asbestos manufacturers sued by covered workers have no right of indemnification against the workers' employers. If the employers are shipowners as well as employers, then asbestos manufacturers may seek indemnification from the employers for any negligence of the employers, in their capacity as shipowners, related to the asbestos-related injuries. The LHWCA allows that:

In the event of injury to a person . . . caused by the negligence of a vessel, then such person, or anyone otherwise entitled to recover damages by reason thereof, may bring an action against such vessel as a third party.

33 U.S.C. § 905(b). Thus, if the asbestos manufacturers can show that the negligence of a shipowner was involved in the asbestos-related injury of the employee, as for example in Castorina, 758 F.2d at 1034-36 (finding no negligence in shipowner capacity), these defendants may be able to recover, through indemnification or contribution, from the shipowner. This is true even if the shipowner is an employer otherwise protected by the exclusivity 
With the exception of the Fourth Circuit in White, all of the courts of appeals that have considered shipyard workers' asbestosrelated direct or third-party claims have rejected attempts to state a valid cause of action in admiralty. ${ }^{10}$ Indeed, recently the Fourth Circuit joined the other circuits in holding that such claims cannot be brought under the maritime jurisdiction. ${ }^{11}$ The courts of appeals have held that the asbestos-related injuries of shipyard workers who installed asbestos on ships on navigable waters ${ }^{12}$ fail to meet the jurisdictional requirement that an injury have a maritime nexus, that is, a connection with the traditional subject matter of the admiralty and maritime jurisdiction. The Supreme Court set forth this requirement in Executive Jet Aviation, Inc. v. City of Cleveland, ${ }^{13}$ and extended it to all claims of tort in admiralty in Foremost Insurance Co. v. Richardson. ${ }^{14}$

This comment argues that the courts of appeals are wrong and that the asbestos claims of shipyard workers injured on navigable waters are within the admiralty jurisdiction of the federal courts.

provision of the LHWCA, section 905(a). For background discussion of this "dual capacity doctrine," and its particular application to the LHWCA, see Arthur Larson, 2A Workman's Compensation Law \$§ 72.81-72.84 (1986).

In 1984, Congress curtailed this type of dual capacity action brought under the LHWCA. Longshore and Harbor Workers' Compensation Act Amendments of 1984, Pub. L. No. 98-426, 98 Stat. 1639,1641 (1984) ( $\$ 5(a) 1$ bars such dual capacity claims brought after this amendment). See also Larson, 2A Workmen's Compensation $\S 72.84$ at 14-249 (Supp. Dec. 1986). Thus, in order to recover damages against the U.S. as shipowner after the 1984 Amendments to the LHWCA, a defendant manufacturer must bring its third-party cause of action under the Federal Tort Claims Act, 28 U.S.C. $\$ 1346$ (1982) ("FTCA") or under state workmen's compensation law. Neither approach seems likely to succeed. See, e.g., Drake v. Raymark Industries, Inc., 772 F.2d 1007, 1016 (1st Cir. 1985) (noting that it is "rather ironic" that the same manufacturers that had argued as first-party defendants that asbestos-related injuries to harbor workers were outside admiralty jurisdiction were arguing for exercise of admiralty jurisdiction as third-party plaintiffs); Larson, 2A Workman's Compensation $\$ 72.82$ at 14-234 (cited in this note) (surveying state law and finding "virtual unanimity" that employer cannot be sued on dual capacity theories as owner of work premises).

${ }^{10}$ See Drake, 772 F.2d 1007; Austin v. Unarco Industries, Inc., 705 F.2d 1 (1st Cir. 1983); Keene Corp. v. United States, 700 F.2d 836 (2d Cir. 1983); Woessner v. JohnsManville Sales Corp., 757 F.2d 634 (5th Cir. 1985); Myhran v. Johns-Manville Corp., 741 F.2d 1119 (9th Cir. 1984); Owens-Illinois, 698 F.2d 967; Harville v. Johns-Manville Products Corp., 731 F.2d 775 (11th Cir. 1984).

11 Oman v. Johns-Manville Corp., 764 F.2d 224 (4th Cir. 1985) (en banc).

12 Injuries that occur on land or on nonnavigable waters are outside the admiralty jurisdiction because they lack a maritime locus. See Executive Jet Aviation, Inc., v. City of Cleveland, 409 U.S. 249, 253 (1972). For general background, see Finneseth v. Carter, 712 F.2d 1041, 1043-44 (6th Cir. 1983) (defining the term "navigability").

13409 U.S. 249 (1972).

14457 U.S. 668 (1982). The Court has recently indicated, however, that the "nexus" requirement may not be applicable to torts on the high seas. See East River Steamship Corp. v. TransAmerica Deleval Inc., 106 S.Ct. 2295, 2298 (1986). 
The comment's first part analyzes the maritime nexus that is necessary for the exercise of admiralty jurisdiction and considers the application of those requirements to tort claims in general and products liability suits in particular. The second part discusses the arguments on which the courts of appeals have based their denial of admiralty jurisdiction and criticizes them in light of relevant Supreme Court pronouncements. In particular, this part also dismisses the courts' policy arguments against jurisdiction: even if one grants the highly questionable proposition that courts may legitimately weigh policy to decide whether or not to exercise the exclusive admiralty jurisdiction given them by statute, the political problems cited by the courts are insignificant. The comment concludes that the circuits that have failed to find admiralty jurisdiction over shipyard workers' asbestos torts have misapplied the maritime nexus test.

\section{The Requirements of Admiralty Jurisdiction}

In order to understand the actual requirements for admiralty jurisdiction over tort cases, it is useful first to review the history and rationale behind the modern cases defining that jurisdiction.

\section{A. Cases Defining the Admiralty Jurisdiction}

The pre-Executive Jet rule of admiralty jurisdiction over tort actions was that set out in 1813 by Justice Story: the grant of admiralty jurisdiction over tort "is exclusively dependent upon the locality of the act."15 In The Genesee Chief $v$. Fitzhugh, ${ }^{16}$ the Supreme Court refined the locality rule to hold that the jurisdiction applied to all torts located on navigable water. ${ }^{17}$ A tort occurred on navigable water when both the "substance and consummation" of the tort took place on such waters. ${ }^{18}$ Aside from an extension of jurisdiction embodied in the Admiralty Extension Act, passed by Congress in $1946,{ }^{10}$ the law remained at this point until 1972, when the Supreme Court handed down its decision in Executive Jet.

15 Thomas v. Lane, 23 F. Cases 957,960 (C.C. Me. 1813) (No. 13,902) (as circuit judge).

16 53 U.S. 443 (1852).

${ }^{17}$ For a survey of the numerous cases setting forth the strict locality rule, see Steven $F$. Friedell, Steven Bellman, Aileen Jenner, and Joan Loo, 2 Benedict on Admiralty $\$ 2$ at 1-6 n.7 (7th ed. 1986).

18 The Plymouth, 70 U.S. 20, 35 (1866).

19 The Act extends the admiralty jurisdiction to "all cases of damage or injury, to a person or property, caused by a vessel on navigable water, notwithstanding that such damage or injury be done or consummated on land." 46 U.S.C. $\S 740$ (1982). 
In Executive Jet the Court ruled that, for an aviation tort to come under the federal maritime jurisdiction, the tort must not only occur on navigable waters but also have a nexus with traditional maritime functions. Executive Jet involved an airplane company that lost one of its planes in Lake Erie shortly after the plane took off from Burke Lakefront Airport in Cleveland. The company claimed negligence on the part of the city, which allegedly allowed a flock of sea gulls to interfere with the takeoff of the plane, and brought suit in admiralty in order to avoid the bar that would have been imposed by the Ohio statute of limitations. The Supreme Court denied jurisdiction on the basis that the accident was "only fortuitously . . . connected to navigable waters" and bore "no relationship to traditional maritime activity."20 The Court noted that the planned flight was intracontinental and would not in any way have duplicated a voyage that could have been taken on navigable waters. ${ }^{21}$ It also argued that if a uniform federal law of aviation was appropriate, Congress was free to construct such a law and that a court should not preempt that choice through "quixotic" exercise of admiralty jurisdiction. ${ }^{22}$ In assessing the jurisdictional issue, the Court looked to see if the tort under the circumstances bore "a sufficient relationship to traditional maritime activity" to come within the admiralty jurisdiction. ${ }^{23}$

The Court emphasized that to draw distinctions based upon where the plane ended up, or where it happened to be when the negligence occurred, would make admiralty tort jurisdiction hinge on circumstances "that could be wholly fortuitous and completely unrelated to the tort itself." ${ }^{24}$ The Court expressed some concern that a tort involving technology not traditionally viewed as maritime would lead a federal court exercising its maritime jurisdiction to enter into "factual and conceptual inquiries unfamiliar to the law of admiralty."26 But it was willing to consider the possibility that aviation torts could come under the admiralty and maritime jurisdiction if there were some nonfortuitous reason for the aircraft's location over navigable water. For instance, the Court said that an airplane performing the "traditional maritime activity" of

${ }^{20}$ Executive Jet, 409 U.S. at 273.

${ }^{21}$ Id. at 272. The Court did not foreclose the possibility that aviation torts involving planes duplicating functions "traditionally performed by waterborne vessels," id. at 271, such as transoceanic flights, may come within admiralty jurisdiction.

22 Id. at 273-74.

23 Id. at 271 .

${ }^{24}$ Id. at 267.

${ }^{38}$ Id. at $270-71$. 
transporting passengers over water might well present a question in admiralty. ${ }^{28}$ Indeed, the Court in later cases has implicitly accepted this view, ${ }^{27}$ as have the courts of appeals. ${ }^{28}$

In Foremost Insurance Co. v. Richardson, ${ }^{29}$ a tort action based on a death caused by the collision of two pleasure boats, the Court announced that a significant relationship with traditional maritime activity was a prerequisite for admiralty jurisdiction over all torts, but this nexus requirement did not necessitate a direct involvement with maritime commerce..$^{30}$ Further, the Court denied that Executive Jet had implicitly overruled prior cases upholding admiralty jurisdiction where the sole connection of the tort to maritime matters was that it had been consummated aboard a ship. ${ }^{31}$ The Court also indicated that any tort involving a negligently operated vessel on navigable waters would provide "sufficient nexus to traditional maritime activity to sustain admiralty jurisdiction." 32

The Court further explained Executive Jet's nexus require-

26 Id. at 271 .

${ }^{27}$ In Mobil Oil Corp. v. Higginbotham, 436 U.S. 618, 618-19 (1978), the Court noted that admiralty jurisdiction had been based on the fact that the helicopter in which plaintiff's decedent was killed had been engaged in the traditional maritime function of transporting workers from land to offshore drilling sites. As the Court noted in Mansfield C. \& L. M. Ry. Co. v. Swan, 111 U.S. 379, 382 (1884), a federal court is required, "of its own motion, to deny its own jurisdiction, and, in the exercise of its appellate power, that of all other courts of the United States, in all cases where such jurisdiction does not affirmatively appear in the record on which, in the exercise of that power, it is called to act." Therefore, because the Court was aware of the jurisdictional question in Higginbotham, see 436 U.S. at $619 \mathrm{n} .2$, and did not answer it by dismissing the case, the Court approved of this exercise of admiralty jurisdiction.

28 See, e.g., Roberts v. United States, 498 F.2d 520 (9th Cir. 1974) (airplane); Barger v. Petroleum Helicopters, Inc., 692 F.2d 337 (5th Cir. 1983) (helicopter). Perhaps the strangest case involving the exercise of admiralty jurisdiction over technology alien to the traditional concerns of the admiralty is that of a boat struck by a heat-seeking air-to-air missile. In T. J. Falgout Boats, Inc. v. United States, 508 F.2d 855 (9th Cir. 1974), a land-based naval aircraft lost control and prior to crashing released a Sidewinder, a short-range air-to-air missile. The missile found its way to the Pacific, where, in what must have appeared to many observers as a bolt from Jupiter rather than a thrust of Neptune's trident, it struck and damaged a fishing vessel. In dismissing a suit against the government brought under the Federal Tort Claims Act, the Ninth Circuit held that admiralty jurisdiction applied. While an errant Sidewinder may not be a traditional concern of admiralty, the court observed, "it [could] not be said that the naval plane's activity over water in the instant case was entirely 'fortuitous' as was the plane involved in Executive Jet." $508 \mathrm{~F} .2 \mathrm{~d}$ at 857.

29457 U.S. 668 (1982).

so Id. at 674 . The Court noted that the primary goal of admiralty jurisdiction was the protection of maritime commerce, but eschewed "too narrow a view of the federal interest sought to be protected." Id.

s1 Id. at 672-73.

32 Id. at 674 . 
ment in Director, OWCP v. Perini North River Associates. ${ }^{33}$ In Perini, a marine construction worker sued his employer under the LHWCA for compensation for injuries sustained while he was working on a sewage treatment facility on the Hudson River. Noting that the LHWCA's definition of "maritime" has no necessary relationship to the interpretation of maritime under 28 U.S.C. $\S 1333(1)$, the Court explained that the Executive Jet nexus requirement between employees and traditional maritime activity arose as a result of

"the problems involved in applying a locality-alone test of admiralty tort jurisdiction to the crashes of aircraft" in a situation where "the fact that an aircraft happens to land in navigable waters, rather than on land is wholly fortuitous." . . . [A] marine construction worker was by no means "fortuitously" on the water when he was injured. ${ }^{34}$

Thus, in Perini the Court characterized the Executive Jet decision as a narrow one, one that denied admiralty jurisdiction over torts that only fortuitously met the age-old locality requirement. Perini also suggests that virtually nothing more than nonfortuitous marine locality is necessary to show the requisite relationship to maritime activity.

\section{B. Modern Admiralty Jurisdiction Over Tort and Products Liability Claims}

Courts have attempted to frame the nexus requirement into a workable test of admiralty jurisdiction over admiralty torts in general and products liability claims in particular. One of the earliest and most influential cases interpreting Executive Jet is Kelly $v$. Smith, ${ }^{35}$ which arose out of a gunfight between a group of poachers in a boat on a tributary of the Mississippi River and a gamekeeper on the river bank. One of the poachers was injured and sued in admiralty to avoid Mississippi's statute of limitations. The defendant challenged the court's jurisdiction, and, in the words of Judge Godbold, "[t]he land detachment won the battle but lost the lawsuit."36

Affirming the district court's exercise of admiralty jurisdiction,

s3 459 U.S. 297 (1983).

34 Perini, 459 U.S. at 320 n.29 (citation omitted), quoting Executive Jet, 409 U.S. at 265-66.

ss 485 F.2d 520 (5th Cir. 1973).

${ }^{36}$ Id. at 521 . 
the Fifth Circuit held that it was necessary to "look to all the circumstances for a substantial maritime relationship." ${ }^{37}$ Accordingly, the court listed four factors to be considered: 1) the function and role of each of the parties; 2) the type of vehicles and instrumentalities involved; 3) the type and causation of the injuries; and 4) the relationship of the tort to the history and purpose of the admiralty jurisdiction. ${ }^{38}$ While the court held that gunshot wounds from a gamekeeper's rifle were not strictly maritime hazards, it nonetheless found jurisdiction because ship travel and the ability to navigate, albeit in a pleasure boat, were involved. The court did not balance the state law interest against the federal interest in maritime matters. Nor did it balance the various factors to determine whether the tort was predominantly maritime; it followed Executive Jet in simply looking to see if there was any maritime relationship sufficient to uphold admiralty jurisdiction. ${ }^{39}$

Courts also have applied the requirements of locality and maritime nexus to products liability actions. ${ }^{40}$ They have exercised admiralty jurisdiction over products liability claims involving suppliers of component parts to vessels, even when the parts were not specifically made for maritime use. ${ }^{41}$ In Sperry Rand Corp. v. Radio Corporation of America, ${ }^{42}$ for example, a shipowner sued Sperry Rand in admiralty for the damage caused by a defect in that company's marine navigation equipment. Sperry settled with the shipowner, and brought an admiralty action of its own against the manufacturer of the component parts, which were not made specifically for maritime use.

In upholding admiralty jurisdiction, the Fifth Circuit noted that as long as Executive Jet's "locality plus" test was met, it was irrelevant where the tort originated. ${ }^{43}$ The court also observed that

37 Id. at 525.

ss Id.

so Id. at 526-28 (Morgan, J., dissenting).

10 See, e.g., Jig The Third Corp. v. Puritan Marine Ins. Underwriters Corp., 519 F.2d 171, 174 (5th Cir. 1975). See also East River Steamship Corp., 106 S.Ct. at 2298-99 (accepting the law of strict products liability in admiralty, but indicating that the nexus may need not be established where the tort occurs on the high seas).

11 See, e.g., Sperry Rand Corp. v. Radio Corporation of America, 618 F.2d 319, 322 (5th Cir. 1980); Bradford v. Indiana \& Michigan Elec. Co., 588 F.Supp. 708, 713-14 (S.D. W.Va. 1984) (following Sperry).

12618 F.2d 319 (5th Cir. 1980).

1s Id. at 321. See also Austin v. Unarco Industries, Inc., 705 F.2d 1, 9-10 (1st Cir. 1983); Bradford, 588 F.Supp. at 713.

In Keene, 700 F.2d 836, the Second Circuit explicitly declined to follow Sperry's reasoning. The Second Circuit's jurisdictional rule focuses instead on the defendant manufacturer's activities and their relation (or lack of relation) to traditional maritime activity. 
the defendants cannot cite one case where the requirement of "significant relationship to traditional maritime activity," added by Executive Jet, was not satisfied by the sinking of, or inflicting of damage upon, a marine vessel on navigable waters. ${ }^{44}$

Thus, the Fifth Circuit held--as it had in Kelly-that while the location of the injury on navigable waters alone will not satisfy the nexus requirement, the location of an injury on a ship nonfortuitously on navigable waters will. Finally, the court observed that the finding of admiralty jurisdiction was necessary to avoid injustice and produce a uniformity of result among the parties in interest, although it did not expressly balance these considerations of policy. ${ }^{45}$

\section{The Denial of Admiralty Jurisdiction Over Asbestos TORTS OF HARBOR WORKERS}

Though the courts of appeals have uniformly denied admiralty jurisdiction over the asbestos-related products liability claims of

Lingo v. Great Lakes Dredge \& Dock 6., 638 F.Supp. 30, 33 (E.D.N.Y. 1986), explaining Keene, 700 F.2d at 844. Thus, the Second Circuit emphasizes whether the manufacturer's product, at the time of the accident, was fortuitously upon the water from the perspective of the manufacturer. But this reasoning seems at odds with the underlying theory of admiralty jurisdiction. The question is not whether the activity of either the defendant or plaintiff prior to the tort bears a sufficient relation to traditional maritime activity, but whether the consummation of the tort itself creates such a nexus, just as it is the consummation of the tort that must provide the jurisdictionally required locus.

Because admiralty jurisdiction is subject matter jurisdiction, it does not matter whether the defendant manufacturer, by making a product, reasonably could have foreseen that by doing so he might be sued in a court of admiralty. Compare World Wide Volkswagen Corp. v. Woodson, 444 U.S. 286, 295-96 (1980) (foreseeability of suit in jurisdiction relevant to personal jurisdiction). Nor is it relevant that defendant manufacturer's product was so rarely used upon the navigable waters that it could not be said to have "enjoy[ed] the benefits and protection of the laws" of admiralty. Compare International Shoe Co. v. Washington, 326 U.S. 310, 315-20 (1945) (personal jurisdiction over defendant with minimal contacts in state).

A tort occurring on the seas and relating to traditional maritime activity is a federal issue that federal courts have been given the power and responsibility to hear. The inquiry is not into a federal court's power to bring the parties before it, but rather whether the federal courts may hear the case at all. Also, the issue is not based on choice-of-law rules, as there are no competing laws from which to choose. But see, In re Peterson v. Chesapeake \& Ohio Ry., 784 F.2d 732 (6th Cir. 1986) (finding no admiralty jurisdiction, but applying substantive maritime law to an asbestos tort). Moreover, the Second Circuit's emphasis on the land-based defendant's perspective would in many instances conflict with the overriding concern of maritime law-the need for uniform law governing the maritime industries. See Sperry, 618 F.2d at 322 ; Kelly, 485 F.2d at 526.

44 Sperry, 618 F.2d at 321 (emphasis added).

4s Id. at 322 . 
harbor workers, none of the courts has denied jurisdiction because the locality requirement was not met. ${ }^{16}$ Instead, the circuits have denied admiralty jurisdiction because they conclude that asbestos claims fail to establish the maritime nexus that Executive Jet requires. The next subsection analyzes the courts' applications of the nexus requirement, focusing on the four-part nexus test established by the Fifth Circuit in Kelly $v$. Smith. ${ }^{47}$

\section{A. Application of Kelly's Test by the Courts of Appeals}

In their determination of whether asbestos cases meet the nexus requirement, five out of the six circuits have adopted the four-part test established by the Fifth Circuit in Kelly, ${ }^{\mathbf{4 8}}$ balancing the factors to determine whether or not the tort bears the significant relation to traditional maritime function required by Executive Jet and Foremost Insurance. ${ }^{49}$ Even though the determination of admiralty jurisdiction often involves "perverse casuistic borderline situations," the circuits that have considered the asbestos cases under the Kelly test have had no difficulty denying admiralty jurisdiction. To understand the courts' holdings it is useful to analyze each of the Kelly factors in turn.

1. The function and role of the parties. The courts have differed in their assessments of the extent to which defendant manufacturers perform maritime functions. In particular, the courts are split as to whether the asbestos products were designed, advertised, and marketed as maritime products; ${ }^{51}$ and they disagree as to the significance to attach to the fact that the products were made exclusively for maritime purposes. Some courts seem to re-

46 The courts have found that workers' exposure to asbestos while working on navigable waters in wet dock is sufficient to meet the locality requirement. See, e.g., Drake, 772 F.2d at 1015 (surveying cases from the Second, Fourth, Ninth and Eleventh Circuits). See also Woessner, 757 F.2d at 638 (5th Cir.).

47485 F.2d at 525. See also text at note 38.

is See Drake, 772 F.2d at 1015-16 (1st Cir.); Woessner, 757 F.2d at 643 (5th Cir.); Oman, 764 F.2d at 230 (4th Cir.); Myhran, 741 F.2d at 1121 (9th Cir.); Owens-Illinois, 698 F.2d at 970 (9th Cir.); Harville, 731 F.2d at 783 (11th Cir.). Only the Second Circuit in Keene, 700 F.2d 836, stands out. The Keene court did not apply any sort of test but simply found that the activities of manufacturers of asbestos "do not bear a significant relationship to traditional maritime activities such as 'navigation and commerce.' "Id. at 844 . For a critique of Keene, see note 43 and accompanying text above.

40e, e.g., Woessner, 757 F.2d at 643.

so Executive Jet, 409 U.S. at 255.

s1 For examples of cases finding the manufacturer to be substantially maritime, see Oman, 764 F.2d at 230; White, 662 F.2d at 240 . Cases finding nonmaritime product design include Harville, 731 F.2d at 784; Keene, 700 F.2d at 844; Woessner, 757 F.2d at 643-44. 
quire that the asbestos be designed specifically for maritime use, ${ }^{52}$ while others reject distinctions drawn on intended maritime design. ${ }^{53}$

Regardless of whether the manufacturer's role tends to justify admiralty jurisdiction, the courts agree that the plaintiffs in asbestos cases do not perform traditional maritime tasks. ${ }^{54}$ While harbor workers may be vital to maritime commerce, the plaintiffs' pipefitting and insulating skills and training are considered to be those of landsmen. ${ }^{55}$ Combining the rather tenuous maritime role of defendants with the land-based nature of plaintiffs' trades, no court has found the first factor to weigh in favor of the exercise of admiralty jurisdiction.

2. The vehicles and instrumentalities. While the vehicles and instrumentalities involved in asbestos cases-ships and their propulsion systems-may seem closely related to the subject matter of admiralty, the courts that have considered the question have concluded otherwise. ${ }^{68}$ Finding that "the involvement of the ships is at most tangential,"s7 the courts note that the nature of plaintiffs' claims is exactly the same as if the claims had arisen while working on a building on land. By focusing on other instrumentalities-asbestos insulation, safety masks, and various other tools and devices common to land-based construction-the courts find no uniquely maritime character that would justify admiralty jurisdiction. ${ }^{58}$

3. The types and causation of the injuries. Asbestos inhalation, according to the courts of appeals, is a harm commonly suffered by landsmen and thus has no special maritime flavor. ${ }^{50}$ That

${ }^{62}$ See, e.g., Keene, 700 F.2d at 844 . See also Oman, 764 F.2d at 230 (asbestos products designed for maritime use favors exercise of admiralty jurisdiction).

${ }^{63}$ See, e.g., Austin, 705 F.2d at 10 (admiralty jurisdiction attaches despite fact that manufacturer's product has "no independent connection to maritime activity").

54 Drake, 772 F.2d at 1016; Oman, 764 F.2d at 230-31; Woessner, 757 F.2d at 641; Myhran, 741 F.2d at 1122; Harville, 731 F.2d at 784-85; Owens-Illinois, 698 F.2d at 971.

ss According to the Fifth Circuit, workers engaging in the repair of insulation vital to the propulsion system of a ship are engaged in a task of which "[t]here is no evidence . . . that marine engineers or any other crew member historically or ordinarily performed." Woessner, 757 F.2d at 646.

ss See, e.g., Oman, 764 F.2d at 231; Woessner, 757 F.2d at 646-47; Myhran, 741 F.2d at 1122; Harville, 731 F.2d at 785; Owens-Illinois, 698 F.2d at 971.

${ }^{\mathrm{B} z}$ Oman, 764 F.2d at 231. See also Owens-Illinois, 698 F.2d at 971 (mere fact that plaintiff is injured aboard ship does not support admiralty jurisdiction).

sB See, e.g., Harville, 731 F.2d at 785.

so Id. See also Woessner, 757 F.2d at 647; Myhran, 741 F.2d at 1122-23; Owens-Mlinois, 698 F.2d at 971 . But see Drake, 772 F.2d at 1016 n.8 (fact that the injury is of the sort suffered by landsmen is not important; rather, the maritime nature of the activity causing 
the harm occurs on or in the service of a maritime vessel is a mere fortuity and does not lend a maritime character to the worker's claim. ${ }^{60}$ Indeed, one court found that the nonmaritime nature of the injuries militates strongly against application of maritime jurisdiction. ${ }^{81}$

4. Relationship to traditional maritime concerns. The courts have given special weight to the relationship of the tort to the history and purpose of the admiralty jurisdiction. ${ }^{62}$ In cases where the first three factors do not clearly support or undermine the exercise of admiralty jurisdiction, history and purpose become determinative: that is, the national interest in asserting maritime jurisdiction is balanced against the interest in preventing the displacement of local law in what may be an essentially local matter. ${ }^{63}$

The courts uniformly have found that jurisdiction over asbestos cases is inconsistent with the history and purpose of admiralty jurisdiction, but their reasoning has varied. Some state that asbestos work done by land-based workers has no real connection with maritime commerce. ${ }^{64}$ Another court has decided that the plaintiffs' claims do not relate to the specific maritime concerns that Executive Jet indicated would establish the requisite connection to the history and purpose of the grant of admiralty and maritime jurisdiction. ${ }^{65}$ Generally, the courts have found that asbestos torts are not related to the discrete and specific body of maritime concerns that justify admiralty jurisdiction. ${ }^{66}$

Nor have the courts found a federal interest in the application of a uniform law to the claims of sailors, longshore workers, and harbor workers, or a need for a specific admiralty doctrine to han-

the injury is dispositive).

${ }^{60}$ Harville, 731 F.2d at 785.

-1 Woessner, 757 F.2d at 647.

62 See Harville, 731 F.2d at 785 (fourth factor "clearly the most important"); Woessner, 757 F.2d at 643 .

as See, e.g., Woessner, 757 F.2d at 643 .

o4 Drake, 772 F.2d at 1016; Oman, 764 F.2d at 232; Woessner, 757 F.2d at 648-49; Myhran, 741 F.2d at 1122-23; Harville, 731 F.2d at 786. The court in Owens-Illinois, 698 F.2d at 970, also noted that many of the injured workers had been injured in the course of the construction of new ships, an activity traditionally outside the scope of admiralty's interest.

os See Harville, 731 F.2d at 786-87. See also Executive Jet, 409 U.S. at 270:

[Maritime] law deals with navigational rules. . . Through long experience, the law of the sea knows how to determine whether a particular ship is seaworthy, and it knows the nature of maintenance and cure. It is concerned with maritime liens, the general average, captures and prizes, limitation of liability, cargo damage, and claims for salvage.

66 See note 59 and accompanying text above. 
dle harbor workers' claims. ${ }^{67}$ To the contrary, they believe that there is a legitimate interest in obtaining uniform determination of asbestos tort actions within a given state, whether the cause of action was related to work on land or to work on a ship in navigable waters. ${ }^{68}$ Some courts express concern that admiralty jurisdiction not be expanded beyond its constitutional and statutory boundaries. ${ }^{69}$

In sum, the circuits have found that all of the Kelly factors weigh against exercising admiralty jurisdiction in asbestos cases, and several other considerations also support this result.

\section{B. Criticism of the Current Approach}

The Kelly factors are simply one court's attempt to give substance to the nexus requirement of Executive Jet, albeit one that other courts have adopted. These factors are not exhaustive, or necessarily relevant, in determining maritime nexus. The discussion in this comment will assume that the Kelly test is a reasonable way to approach the question of whether a particular tort has a significant connection to traditional maritime activity. However, this test has been misused by the circuits in shipyard workers' asbestos cases.

1. The inappropriateness of a balancing test. Executive Jet and Foremost Insurance do not undertake a balancing test in determining whether to exercise admiralty jurisdiction over tort cases. In Executive Jet, the Court ruled that there was no relation between the tort and traditional maritime activity; and in Foremost Insurance, jurisdiction was upheld despite a tenuous relationship between the alleged tortfeasor and the traditional admiralty concern of maritime commerce. It might be argued that the Court in Foremost Insurance maintained jurisdiction because it was of uppermost importance to maritime commerce that the waterways be kept free of negligent helmsmen, whether navigating in the pursuit of commercial gain or not. ${ }^{30}$ But the fact that the Court specifically reaffirmed the pre-Executive Jet cases (which found admiralty jurisdiction in cases with little maritime flavor under the strict locality test) shows that no preponderant maritime concern

87 See, e.g., Woessner, 757 F.2d at 648; Harville, 731 F.2d at 786.

ss See, e.g., Woessner, 757 F.2d at 648-49.

69 See Executive Jet, 409 U.S. at 272-73 (courts should proceed with caution in expanding admiralty jurisdiction without a congressional mandate); Woessner, 757 F.2d at 648-49.

70 Foremost Insurance, 457 U.S. at 675. 
is necessary. ${ }^{71}$

The determinant of admiralty jurisdiction over tort suits should not be a balancing of factors, but rather whether the facts present any substantial indicium of traditional maritime activity that demonstrates that the tort's occurrence over navigable waters was not fortuitous. Hence, a substantial showing of traditional maritime relation under any one Kelly factor should be sufficient to trigger such jurisdiction. Furthermore, weak showings on particular factors should not subtract from the weight of maritime nexus indicated by other factors. ${ }^{22}$ The question is not whether the maritime indicia outweigh those indicating jurisdiction at law or equity. In fact, in tort cases that do not involve asbestos, the lower courts have looked for any nonfortuitous connection between the tort and maritime concerns and have not read the test of Foremost Insurance and Executive Jet to require preponderant maritime nexus. ${ }^{73}$

2. Misapplication of the Kelly factors. Contrary to the opinions of the courts of appeals, all of the four factors in the Kelly analysis should weigh in favor of the exercise of the admiralty jurisdiction when harbor workers are injured by asbestos.

a. The function and role of each of the parties. Even if it is conceded that the functions and roles of defendant asbestos manufacturers are unrelated to traditional maritime concerns, the circuits have erred in failing to recognize that the functions and roles of shipyard workers are closely related to traditional maritime activity.

The circuits have given two flawed reasons for finding that shipyard workers are not performing a maritime function. The first reason-applicable only to some workers-is that the workers were engaged in ship construction (in wet-dock), which is not a traditional maritime activity, ${ }^{74}$ rather than ship repair, which is a traditional maritime activity. ${ }^{75}$ But the distinction between work per-

71 Id. at 672 . In one of the cases noted by the Court, the injury was the result of carbon monoxide poisoning aboard a pleasure boat. See Just v. Chambers, 312 U.S. 383 (1941). See also text accompanying notes $93-95$ below.

${ }^{72}$ For an example of a case in which Kelly seemed to be applied negatively, see Woessner, 757 F.2d at 647 (nonmaritime nature of injuries "yet another factor to be weighed against application of maritime law").

73 See notes 27,28 , and 41 above.

74 See Drake, 772 F.2d at 1016-18 \& nn.9, 10; Owens-Illinois, 698 F.2d at 970.

78 The historical basis for this distinction is summed up in Tucker v. Alexandroff, 183 U.S. 424, 438 (1902) ("Prior to her [a ship's] launching she is a mere congeries of wood and iron . . . as distinctly a land structure as a house. ... In the baptism of launching she receives her name, and from the moment her keel touches the water she is transformed, and becomes a subject of admiralty jurisdiction."). 
formed under a contract for construction and work performed under a contract for repair is irrelevant to the issue of a worker's connection with maritime concerns. Whether the work he performs is part of a maritime contract decides only whether the agreement itself is a subject of maritime interest; it does not decide the connection of the activity with maritime concerns. ${ }^{76}$ Maritime tort analysis is different from contract analysis. While a contract to build a ship is nonmaritime, other factors involved in a tort arising out of a nonmaritime contract can satisfy the nexus requirement. ${ }^{27}$ If a tort arising out of a nonmaritime contract is able to satisfy the nexus and locality requirements, then the action is within the jurisdiction of admiralty. ${ }^{78}$

The second reason given by the circuits for finding that the function of shipyard workers is unrelated to traditional maritime activity is that their function is not traditionally associated with the sea. While it may be true that asbestos insulation is more related to land-based construction work than to any maritime activity, ${ }^{79}$ the appropriate question is not whether an activity relates to or is performed by landsmen, but whether it is related to a function of the maritime world. Viewed as part of the maintenance or construction of a ship's propulsion system, installation of asbestos insulation would seem both closely linked and vital to maritime commerce. Thus considered, installation of asbestos insulation is analogous to the repair of spars or sails on a wind-powered vessel. ${ }^{\mathbf{8 0}}$

76 Frank L. Maraist, Developments in the Law, 1983-1984: Admiralty, 45 La. L. Rev. 179, 180-81 (1984):

[Some] courts have indicated that exposure ... during ship construction will not [come under admiralty]. [This approach] may have missed the mark. Maritime law distinguishes between construction and repair of vessels in determining which contracts fall within admiralty jurisdiction, but the distinction is primarily historical and can be supported on policy grounds which are foreign to the issue of whether an asbestosis claim by an injured shipyard worker is maritime.

${ }^{77}$ See Austin, 705 F.2d at 10 ("nature of a contract dispute . . . sheds little light on the nature of this products liability claim"). For the criticism that reliance on the distinction between shipbuilding and ship repair contracts may lead to arbitrary results in tort suits, see id. at 12-13 n.5.

${ }^{78}$ For example, in Weinstein v. Eastern Airlines, Inc., 316 F.2d 758 (3d Cir. 1963), the court found a maritime tort arising out of the performance of a nonmaritime contract for carriage by plane. See also Kuehne \& Wagel LAG \& Co. v. Geosource Inc., 625 F.Supp. 794, 798 (S.D. Tex. 1986) (finding a maritime tort of misrepresentation could arise out of a nonmaritime contract for affreightment). But see Hollister v. Luke Construction Co., 517 F.2d 920, 921 (5th Cir. 1975) (injury to welder on incomplete hull not cognizable at admiralty).

70 See note 51 and accompanying text above.

so See McCarthy v. The Bark Peking, 716 F.2d 130 (2d Cir. 1983), in which the court deemed that the LHWCA covered a painter of the spars and mast of an out-of-commission ship on navigable waters; this finding enabled him to bring an action under the Suits at 
Indeed, in its initial consideration of this issue, the Fourth Circuit found that installation of insulation materials was "clearly essential to the maritime industry." ${ }^{21}$

In addition, the Supreme Court has long held that workers' activities that do not have a substantial connection to maritime concerns enjoy admiralty jurisdiction. In Atlantic Transport Co. $v$. Imbrovek, ${ }^{82}$ the Court stated that although the loading and unloading of ships had become a "specialized service," it had a maritime relationship sufficient to confer admiralty jurisdiction. ${ }^{83}$ Later, in Seas Shipping Co. v. Sieracki, ${ }^{84}$ the Court allowed a longshore worker to maintain an action based on the warranty of seaworthiness, a remedy traditionally afforded only to sailors. The lower courts have continued to hear longshore worker claims in admiralty. For example, in Castorina v. Lykes Bros. S.S. Co., Inc., ${ }^{88}$ the Fifth Circuit upheld jurisdiction over asbestos claims of longshore workers doing stevedoring work loading and unloading asbestos materials aboard ship.

Congress treats longshore and harbor workers the same under the LHWCA, ${ }^{86}$ a statute based on the same constitutional grant of jurisdiction as $\S 1333(1)$. Admiralty courts should clearly articulate any distinctions they make between these workers in their jurisdictional decisions. Like the longshore worker in Castorina and the injured marine construction worker in Perini, those who repair asbestos on ships are not on the water fortuitously, but are doing work integrally related to the operation of a ship. Because harbor workers who install asbestos insulation in ships are engaged in

Admiralty Act, 33 U.S.C. $\S 905$ (b), which allows an injured party to bring a maritime in rem action against the vessel on which he was working. See also Woessner, 757 F.2d at 645 (noting that ship's engineers carry asbestos cement in the event that repairs are necessary at sea).

31 White, 662 F.2d at 239 ("Without such shipyard efforts, these vessels would have been unable to perform their maritime roles as carriers of people and cargo.").

2234 U.S. 52 (1914). crew").

ss Id. at 62 (finding that "[f]ormerly the [longshoremen's] work was done by the ship's

For the criticism that Imbrovek was based on a historically inaccurate perception that longshore workers were not separate from the crew of the ship, see Frank L. Tetrault, Seamen, Seaworthiness, and the Rights of Harbor Workers, 39 Cornell L. Q. 381, 414 (1954) ("[There is] no factual basis . . . for assimilating the longshoreman to the mariner."). For a somewhat less convincing defense of the like treatment of longshore workers and sailors, see Comment, Risk Distribution and Seaworthiness, 75 Yale L. J. 1174, 1179-80 (1966) ("[T]he Supreme Court had good reason to find a close historical relationship between the two occupations.").

328 U.S. 85 (1946).

so 758 F.2d 1025 (5th Cir. 1985).

so See 33 U.S.C. \& 902(3). 
traditional-though now highly technical-ship's work, they demonstrate at least as strong a relationship to maritime activity as the workers in Perini and Castorina.

b. The types of instrumentalities and vehicles involved. There is no denying, as the circuits have noted, that the instrumentalities involved in asbestos work-insulation and the tools used in its installation-provide no significant relationship to maritime activities. But the circuits have not given due regard to the fact that the vehicles involved-seagoing ships-are inextricably linked to all maritime concerns. Kelly's inquiry into the type of vehicle was almost certainly an attempt to parallel the Supreme Court's analysis of the maritime relation of the airplane in Executive Jet. One function of Executive Jet's nexus requirement was to distinguish harms that occur on ships from harms that occur on vehicles, like planes, that may be on navigable waters only fortuitously.

This understanding of the role of the vehicles involved is critical to any sensible explanation of the result in Kelly. The injury in Kelly resulted from rifle fire from a gamekeeper, whose rifle had no relation to maritime activity; nevertheless, the fact that the plaintiff was in a boat provided a maritime nexus. ${ }^{87}$ Likewise, the fact that the asbestos exposure that led to the shipyard workers' asbestosis took place aboard oceangoing vessels should provide the requisite nexus.

This reading of Kelly does not signal a return to the localityonly requirement for admiralty jurisdiction. Many types of injuries that occur on navigable waters do not involve seagoing vessels-for instance, the drowning of a swimmer or the crash of a train or plane into a navigable body of water. It was this sort of activity that the Court in Executive Jet intended to preserve for the jurisdiction of the states. ${ }^{88}$

c. The type and causation of the injury. Asbestosis and the inhalation of asbestos fibers have nothing uniquely maritime about them. Yet as the Eleventh Circuit acknowledged in Harville $v$. Johns-Manville Products Corp., "[1]ike the gunshot wounds in Kelly, the plaintiffs' maladies may not be 'so inherently indigenous to land as to preclude any maritime connection." "89 Nevertheless,

${ }^{87}$ See 485 F.2d at 526.

${ }^{88}$ See Executive Jet, 409 U.S. at 266 (" 'while distinctions based on locality often are in fact quite relevant where water vessels are concerned, they entirely lose their significance where aircraft . . . are concerned" ") (citations omitted).

${ }^{88}$ Harville, 731 F.2d at 785, citing Kelly, 485 F.2d at 526. 
even that court declined to exercise admiralty jurisdiction over asbestos claims because asbestosis was not unique to maritime activities. ${ }^{p 0}$ This analysis is inconsistent with the proper application of the nexus requirement to other torts and with the Supreme Court's holdings in Executive Jet, Perini, and Foremost Insurance.

Any classification of injuries in the abstract as either inherently maritime or inherently land based is highly artificial. Virtually any injury that can befall a sailor can befall a landsman. Just as a sailor may slip on the deck and break his leg, so may a landlubber slip on the sidewalk and break his leg. In the abstract, a slip-and-fall accident is neither inherently maritime nor inherently land based.

The same is true for injuries caused by inhalation of asbestos; they are neither inherently maritime nor inherently land based. The courts' treatment of harbor workers' asbestos torts is patently inconsistent with their analysis of other torts, where they generally have avoided the error of classifying types and causes of injuries in the abstract. For example, in Just v. Chambers, ${ }^{91}$ the Court implicitly maintained admiralty jurisdiction over a tort claim involving the carbon monoxide poisoning of a guest on a pleasure boat. The only connection in Chambers with the traditional subject matter of admiralty was that the harm befell a passenger on a ship. Certainly asbestos contamination of the harbor workers' lungs is no less inherently related to maritime concerns than carbon monoxide poisoning: if either occurs on a ship on navigable waters, admiralty jurisdiction should follow. As Perini noted, the test is one of fortuitousness, and a maritime worker's connection with the water is hardly fortuitous.92

Finally, the sheer volume of ship-related asbestos injuries would seem to indicate a strong nexus between asbestosis and maritime industries, ${ }^{98}$ whereas the fortuity noted in Executive Jet indicates a lack of frequency. It is not often that intracontinental

90 Id.

92312 U.S. 383 (1941). In Foremost Insurance, the Court specifically reaffirmed its decision in Chambers. 457 U.S. at 672-76.

9245 U.S. at 320 n.29.

23 See Deborah R. Hensler, William L.F. Felstiner, Molly Selvin \& Patricia A. Ebener, Asbestos in the Courts, 15-16 \& n.4 (1985) (reporting that one of three major categories of asbestos claimants are workers in shipyards during and after World War II; in 1983, these workers brought 51 percent of the asbestos claims then pending). Recently revised OSHA asbestos standards summarize the magnitude of the asbestos problem in shipbuilding and repair industries. OSHA estimates that 15,000 workers at 400 work sites will be affected by the new standards, compliance with which will cost the maritime industries roughly $\$ 3.9$ million. 51 Fed. Reg. 22612, 22651, Table 9, and 22668, Table 27 (June 20, 1978). 
flights crash into water. Moreover, a recent amendment to the LHWCA $^{94}$ recognizes long-latency diseases as being of special concern to maritime workers. ${ }^{95}$ Although the First Circuit has refused to apply the admiralty jurisdiction to asbestos torts of harbor workers, ${ }^{96}$ it has recognized that it is not the nature of the disease that compels this decision. On the contrary, the court noted, the congressional intent expressed in the 1984 LHWCA amendments "bolsters the case for not using the type of injury as part of the hurdle for maritime tort actions." "97

d. Relationship to the history and purpose of admiralty laws. Sailors and those who undertake sailors' duties are traditional wards of the maritime law.98 Similarly, those who undertake maritime work on behalf of a ship have been a concern of admiralty ${ }^{98}$ Implicit in the doctrines of seaworthiness and maintenance and cure $^{100}$ is an admiralty interest additional to those listed in Executive Jet: ${ }^{101}$ the great concern with the well-being of sailors and those who do sailors' work. ${ }^{102}$ Sailors, considered to be friendless, ${ }^{103}$ are given favorable treatment. ${ }^{104}$ Because harbor workers

94 Pub. L. No. 98-426, 98 Stat. 1639, 1641 (1984), codified at 33 U.S.C. §§ 901-52.

${ }^{95}$ The 1984 amendment expanded the definition of disability to include occupational diseases that manifest themselves subsequent to a claimant's date of retirement, 33 U.S.C. $\S \S 902(10), 910(d)(2)$, and to allow time periods measured from the date of injury to be measured from the date when the claimant became aware, or should have become aware through the exercise of reasonable diligence, of the work-related nature of the disease. 33 U.S.C. $\$ 910$ (d)(2). "[The new amendment] amends the current law in several significant respects to insure that long-latency occupational disease claimants do not continue to encounter the severe procedural hurdles which the Longshore Act has presented in the past." Longshore and Harbor Workers' Compensation Act Amendments of 1984, H.R. Rep. No. 98570, on P.L. 98-426, 98th Cong., 2d Sess. 10 (1984).

${ }^{96}$ Drake, 772 F.2d at 1016.

${ }^{97}$ Id. at 1016 n.8.

${ }^{98}$ Seas Shipping Co., 328 U.S. at 99.

99 Id.

100 Maintenance and cure is the right of a sailor to receive medical expenses and payment towards living expenses from her employer when injured in the course of her maritime duties. For a discussion of this obligation, see, e.g., Vaughan v. Atkinson, 369 U.S. 527 (1962).

${ }^{102}$ See note 65 above.

102 See, e.g., Seas Shipping Co., 328 U.S. 85.

${ }^{103}$ See, e.g., the couplet of Judge Becker in Mackensworth v. American Trading Transportation Co., 367 F.Supp. 373, 374 (E.D. Pa. 1973): "The pleaded facts remind us of a tale that is endless. A seaman whom for centuries the law has called 'friendless.' "

For more persuasive if somewhat less whimsical authority, see Garrett v. Moore-McCormack Co., 317 U.S. 239, 246 (1942), quoting Hardlen v. Gordon, 11 F.Cases 480, 485 (C.C.D. Me. 1823) (No. 6,047) (Story, J.) ("[Seamen] are emphatically the wards of the admiralty ... [and] are treated in the same manner as courts of equity are accustomed to treating young heirs, dealing with their expectancies, wards with their guardians and cestuis que trustent with their trustees."). 
who work in asbestos installation undertake the historical maritime duty of repairing and maintaining the propulsion system of a seagoing vessel, they should be afforded the same protection that the Court has granted longshore workers, who undertake the traditional maritime function of stevedoring.

Instead of looking to the traditional role of admiralty law in protecting maritime workers, courts have considered a variety of policies under the rubric of the fourth Kelly factor. No matter how compelling the policy concerns may be, however, when the locality and nexus requirements of the exclusive federal admiralty jurisdiction have been satisfied, a federal court normally cannot refuse to exercise its judicial power. ${ }^{105}$ Congress presumably made a policy choice regarding the appropriate extent of federal jurisdiction when it passed the jurisdictional authorization. ${ }^{106}$ Consequently, it is not clear on what grounds the courts consider various policy rationales in refusing admiralty jurisdiction over asbestos injuries of shipyard workers. ${ }^{107}$

Courts most often emphasize the states' interest in uniform treatment of a particular class of asbestos claims within their jurisdictions. ${ }^{108}$ The federal courts also are generally reluctant to establish a federal common law of products liability for asbestos. ${ }^{109}$ In addition to being arguably outside the courts' purview, these policy objections are unpersuasive in their own right.

First, if the federal courts find the state interest strong or the admiralty interests weak-or where admiralty jurisdiction seems mandated but where no clear admiralty law exists-the federal courts can apply local law under the admiralty jurisdiction. The federal interest as set forth by Congress is protected to some ex-

104 See, e.g., Emerson G.M. Diesel Inc. v. Alaskan Enterprise, 732 F.2d 1468, 1472 (9th Cir. 1984) ("[s]eamen are the favorites of admiralty").

${ }^{105}$ See Colorado River Water Conserv. Dist. v. United States, 424 U.S. 800, 818 (1976). Federal courts have a "virtually unflagging" obligation to exercise jurisdiction. Id. Abstention is the rare exception and not the rule and will be exercised only to allow a state court to determine the constitutionality of a state law, to determine important matters of state law policy programs, or to proceed with a state criminal proceeding. Id. at 813-17. Setting the law of asbestos torts for harbor workers does not fall into any of these categories. Moreover, while the above instances may compel a refusal to exercise jurisdiction in the face of a concurrent state proceeding, for reasons of comity and federalism, such a proceeding is not generally at issue in harbor workers' asbestos cases.

106 The Judiciary Act of 1789 contained the grant of admiralty jurisdiction now found at 28 U.S.C. $\S 1333(1)$.

${ }^{107}$ See, e.g., Austin, 705 F.2d at 13 (noting that the state has an interest in uniform treatment of asbestos victims.)

${ }^{108}$ See, e.g., Woessner, 757 F.2d at 649.

${ }^{109}$ See Jackson v. Johns-Manville Sales Corp., 750 F.2d 1314, 1323-27 (5th Cir. 1985). 
tent simply by having the hearing in a federal forum with all of admiralty's procedural devices, even if local substantive law is applied..$^{110}$

Second, the law of admiralty is not nationwide; it has no effect on landlocked torts and is only a law for that area in which there is a constitutionally and congressionally recognized federal interest. Surely there could be no serious complaint based on federalism concerns against admiralty exercising its jurisdiction over the claims of "blue water" sailors-the members of a ship's crew-against asbestos companies for injuries sustained on the high seas. ${ }^{111}$

A final consideration leading the circuits to refuse to exercise the admiralty jurisdiction may be a desire to avoid creating a perceived anomaly. If the admiralty jurisdiction applies to cases involving asbestos-related injuries suffered by harbor workers working on ships in navigable waters, then a small group of all harbor workers' claims will come under the admiralty jurisdiction with all its "rules and precepts peculiar to the law of the sea," "112 while the rest will be subject to the somewhat different law of the land. However disturbing such an anomaly might be, it is not unique to asbestos torts; it occurs with respect to all torts involving harbor workers. It is a result of the ancient but still-vital locality requirement, ${ }^{113}$ which was retained by the Court in Foremost Insurance ${ }^{114}$

110 For example, see Wilburn Boat Co. v. Fireman's Fund Ins. Co., 348 U.S. 310 (1955). In Wilburn Boat, the Court approved of the exercise of the admiralty and maritime jurisdiction in a case involving the burning of a small boat on a navigable lake between Texas and Oklahoma. However, the Court declined to fashion a federal common law of maritime insurance, and it held that Texas law should apply. The Court noted the minimal need for a national maritime law to cover the facts of the case, and the powerful interest of the states in the regulation of the insurance industry within their territories, as demonstrated by the McCarran-Ferguson Act, 15 U.S.C. $\S \S 1011-15$ (1982), which declares that "the continued regulation . . . of the business of insurance is in the public interest." 15 U.S.C. \& 1011.

${ }^{111}$ Consider, in this regard, Vaughan v. Johns-Manville Corp., 662 F.2d 251 (4th Cir. 1981) (admiralty jurisdiction existed in executrix's wrongful death action arising from the death, due to asbestos exposure, of husband who had been a boiler tender in the Navy). See also note 14 above.

112 See note 3 and accompanying text above.

${ }_{113}$ An example of the anomalous effect of the locality rule may be seen in Holland v. Sea-Land Service, Inc., 655 F.2d 556 (4th Cir. 1981). There, in a third-party action, a longshore worker injured dockside in Virginia was held to that state's strict contributory negligence standard; yet if the same worker had suffered his injury shipside, he would have had the benefit of admiralty's regime of comparative negligence.

${ }^{214}$ Foremost Insurance, 457 U.S. at 672 . For the argument that the locality requirement should be eliminated, see, e.g., Alfred S. Pelaez, Admiralty Tort Jurisdiction: The Last Barrier, 7 Duquesne L. Rev. 1, 41-43 (1968); Maraist, 45 La. L. Rev. at 224 (cited in note 76). 
and which lower courts must follow.

\section{ConcLusion}

All of the circuits that have examined the applicability of the federal admiralty and maritime jurisdiction to the products liability claims of harbor workers engaged in asbestos installation on ships in navigable water have rejected the application of that jurisdictional power on the grounds that the workers' claims do not meet the nexus requirement established in Executive Jet and Foremost Insurance. Unfortunately, the circuits have misunderstood the mandate of the Supreme Court, and their analysis of maritime nexus has misapplied the factors set forth in Kelly. In failing to recognize the nexus between maritime activities and asbestos torts, the courts have denied admiralty's care to one of its primary interests, the protection of those who endure hazard in a ship's service. 